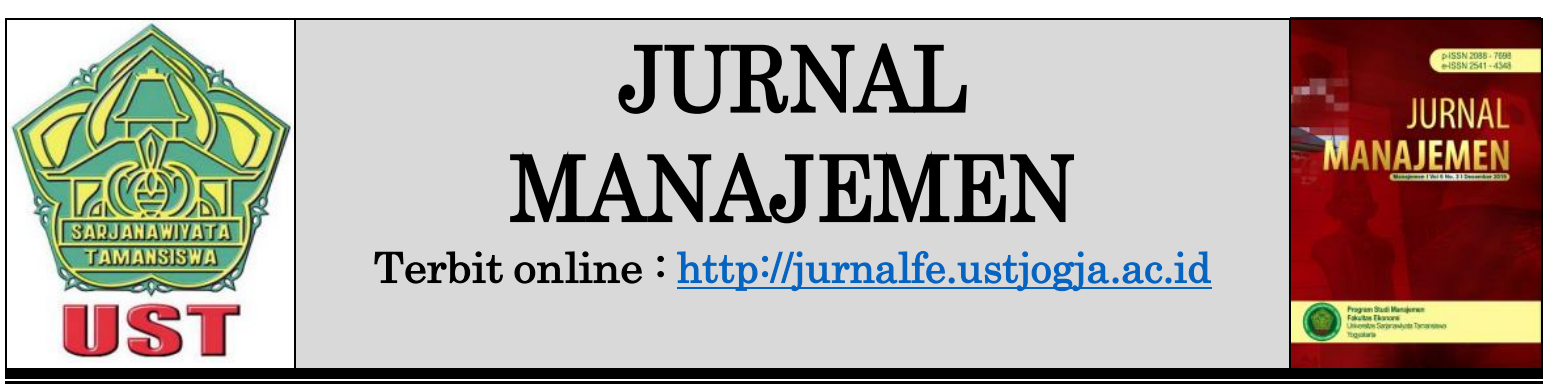

\title{
ONO REGO ONO RUPO: EFEK PLASEBO HARGA DAN KONSUMSI HEDONIS DI MAL KOTA YOGYAKARTA
}

\author{
Faizal Ardiyanto ${ }^{1}$ \\ M. Sulkhanul Umam² \\ ${ }^{1,2}$ Universitas PGRI Yogyakarta
}

\begin{tabular}{lc}
\hline Informasi Naskah & Abstrak \\
\hline Diterima: & There are interesting phenomena related to consumer \\
12 Juli & behavior in Yogyakarta. One of them is price placebo effect. \\
Revisi: & In Javanese language can be found words in relevance with \\
11 Oktober & price placebo effect, that is "ono rego ono rupo" which can be \\
Terbit: & translated to where there is price, there is quality. \\
16 Desember & Therefore, this research is aimed to prove the influence \\
\hline Kata Kunci: Ono Rego & of price placebo effect on brand equity and hedonic \\
Ono Rupo, Price & consumption, atmospheric cues on hedonic consumption, \\
Placebo Effect, & and also the influence of hedonic consumption on brand \\
Hedonic & equity and impulsive buying behavior. \\
Consumption, Brand & Path analysis is used to test the hypotheses and the \\
Equity, Atmospheric & total of 506 respondents are participated in this research. \\
Cues, Impulsive & The result indicated that all of this research hypotheses are \\
Buying Behavior & supported \\
\hline
\end{tabular}

\section{PENDAHULUAN}

Pertumbuhan pusat perbelanjaan secara pesat selama dekade terakhir ini di Daerah Istimewa Yogyakarta memberikan kemudahan dan pilihan bagi konsumen yang suka berbelanja. Hal ini menyebabkan sifat konsumtif konsumen akan lebih mudah untuk diekspresikan. Meskipun beberapa pusat perbelanjaan di Yogyakarta berada pada lokasi yang cenderung mengalami kemacetan, hal ini tidak menghalangi niat para shopping goers untuk berjalan-jalan dan bahkan mungkin membeli produk fashion atau apparel (baju, celana, sepatu, pakaian, dan lain sebagainya) atau kuliner makanan dan minuman yang sebenarnya tidak direncakanan sebelumnya. Sehingga, secara tidak kita sadari, setiap mal atau pusat perbelanjaan membentuk suatu gaya hidup konsumen jaman modern serta perilaku konsumsinya.

Perilaku konsumtif masyarakat, konsumen, atau mahasiswa di Yogyakarta yang tinggi dapat menimbulkan suatu kondisi "pecandu belanja" atau istilah dalam bahasa inggris disebut shopaholic. Kondisi ini cenderung mengarah kepada konsumen usia muda atau sebagian besar dialami oleh usia sekolah atau perkuliahan (pada mahasiswa) baik laki-laki ataupun perempuan. Banyaknya jumlah mahasiswa yang berada di kota-kota besar di Indonesia khususnya di Yogyakarta menjadikan mahasiswa sebagai target pasar tersendiri yang cukup menjanjikan bagi para pelaku bisnis, pemasar, manajemen, dan pihak mal serta pusat perbelanjaan. Perilaku 
konsumtif juga tidak terlepas dari sifat konsumsi hedonis konsumen yang cenderung menyukai merek yang dapat meningkatkan image atau citra di hadapan orang lain. Perilaku mereka dapat terlihat dalam bergaul atau bersosialisasi dalam masyarakat. Mereka biasanya akan selalu berpenampilan menarik, mengenakan fashion bermerek (branded) mengikuti perkembangan zaman dengan sangat cepat. Rata-rata cara berpenampilan tersebut cenderung memperlihatkan standar hidup golongan menengah ke atas. Meskipun pada kenyataannya tidak semua konsumen yang memiliki status shopaholic ini datang dari kalangan masyarakat menengah ke atas. Terdapat pula mahasiswa yang berstatus ekonomi menengah ke bawah juga memiliki pola konsumsi hedonis yang untuk mendapatkan pengakuan sosial (social recognition) dan citra diri (Situmeang, 2017).

Harga merupakan salah satu faktor penting yang dipertimbangkan oleh konsumen untuk melakukan pembelian. Secara tradisional nilai utilitas suatu produk yang ditawarkan oleh perusahaan adalah berdasarkan pada manfaat yang diperoleh atas produk tersebut (Ling et al., 2012). Konsumen sering melakukan pembandingan antara harga dengan kualitas. Anggapan bahwa semakin tinggi kualitas suatu barang maka akan semakin tinggi pula harganya. Persepsi tersebut tidak sepenuhnya salah, karena untuk memproduksi barang yang berkualitas maka perusahaan membutuhkan bahan baku yang berkualitas pula. Meskipun demikian banyak pula barang yang berkualitas tetapi dijual dengan harga yang murah. Penjual harus berhati-hati dengan penetapan harga barang yang murah tetapi mengklaim bahwa barang tersebut memiliki kualitas yang baik. Oleh karena itu, dapat diketahui bahwa konsumen juga sangat sensitif terhadap harga, bahkan di Yogyakarta sendiri terdapat istilah dalam bahasa Jawa disebut dengan "ono rego ono rupo" , apabila diterjemahkan secara implisit menjelaskan bahwa semakin tinggi kualitas suatu barang, maka akan semakin mahal pula harganya.

Kondisi pertokoan menjadi salah satu faktor yang dapat memunculkan hasrat berbelanja konsumen sehingga banyak mal-mal di Yogyakarta membuat kondisi pertokoan yang terawat, rapi, bersih, dan memiliki nuansa yang unik. Tentunya konsumen lebih menyukai toko dalam kondisi bersih dan rapi daripada toko yang kotor dan berantakan. Terkadang toko di mal menggunakan cat yang beraneka ragam corak warnanya, gradasi warna, dan gambar-gambar yang bertujuan minimal untuk mendapatkan perhatian dari konsumen. Aroma, bau, dan wewangian yang sedap, umumnya digunakan guna menarik atau merangsang indera pembau (hidung) pengunjung. Selain itu, mal juga tidak lupa untuk memperdengarkan suara musik atau alunan lagu yang juga digunakan untuk menarik pengunjung. Dapat disimpulkan bahwa inilah yang dapat membangkitkan keinginan untuk membeli dan merangsang mereka untuk melakukan pembelian.

Dalam perilaku konsumen terdapat dua jenis orientasi terhadap suatu produk yaitu konsumsi hedonis dan utilitarian (Ballantine et al., 2010; Kesari \& Atulkar, 2016; Kim \& Kim, 2014; Lim \& Ang, 2008; Ryu et. al., 2010). Kedua hal ini sudah banyak mendapatkan sorotan dari pebisnis karena dapat meningkatkan laba perusahaan mereka. Dalam konsumsi hedonis, konsumen cenderung melakukan konsumsi untuk kesenangan (pleasure) (Alba \& Williams, 2013). Sementara menurut Kamus Besar Bahasa Indonesia konsumsi adalah pemakaian barang hasil produksi. Dapat disimpulkan bahwa, konsumsi hedonis berarti kesenangan untuk menggunakan atau pemakaian produk berupa jasa atau barang. Terkadang konsumen yang memiliki perilaku ini sangat mempedulikan masalah merek, terutama untuk merek produk eksklusif. Perilaku ini lebih cenderung mengarah ke pola konsumsi yang didasarkan pada kebutuhan. Sementara itu, konsumsi utilitarian bertolak belakang dari konsumsi hedonis. Konsumsi utilitarian merupakan perspektif konsumen yang membantu memperjelas batas antara tujuan dengan keinginan terhadap suuatu barang. Misalkan 
seorang konsumen ingin membeli baju yang menurutnya bagus tetapi sebenarnya dia tidak butuhkan atau membeli baju yang murah tetapi benar-benar sesuai dengan kebutuhannya. Konsumen dengan tipe utilitarian, cenderung memilih barang yang berguna dan sesuai dengan kebutuhan. Pada penelitian ini, variabel yang digunakan adalah konsumsi hedonis.

Perusahaan berlomba-lomba untuk melakukan positioning terhadap brand yang mereka miliki. Positioning merupakan cara perusahaan menanamkan citra produknya di benak konsumen, dengan tujuan untuk membedakan produk tersebut dengan produk pesaing- pesaingnya. Selain itu, perusahaan juga melakukan positioning nilai apa sajakah yang ditawarkan kepada konsumen. Value yang dapat diinginkan dan diingat oleh konsumen merupakan salah satu komponen yang membentuk brand equity. Toko-toko yang terdapat di mal Yogyakarta tentunya menjual produk dengan merek yang sudah mendapatkan tempat di benak konsumen. Perusahaan tersebut sebelumnya sudah menciptakan brand equity di produk mereka dengan memproduksi barang yang mudah diketahui, mudah dilihat, namanya mudah diingat, warna dan nuansa produk, kemasan produk, kualitasnya unggul dibanding pesaing, dan atribut-atribut produk lainnya.

\section{KAJIAN PUSTAKA DAN HIPOTESIS Efek Plasebo Harga}

Efek plasebo merupakan imitasi perawatan medis, tanpa kehadiran konstituen terapi khusus (Kienle \& Kiene, 1997). Dengan kata lain, efek plasebo merupakan substansi perawatan yang tidak memiliki dampak terapi sehingga pasien merasa sedang dalam perawatan aktif. Dampak yang dapat ditimbulkan adalah, pasien mungkin bisa merasakan dampak positif dari gejala penyakit yang diderita berupa kesembuhan. Selain itu, pasien juga berpikir bahwa perawatan dapat menimbulkan dampak negatif (efek samping) dari perawatan tersebut. Efek ini muncul ketika harapan dan kepercayaan pasien terhadap medikasi yang mereka konsumsi dapat menghasilkan manfaat kesehatan, meskipun pengobatan tersebut sebenarnya lembam (Stewart-Williams \& Podd, 2004).

Istilah efek plasebo tersebut kemudian diimplementasikan dalam bidang ilmu pemasaran dan digabungkan dengan variabel harga sehingga terbentuk variabel efek plasebo harga (Kim \& Shawn, 2013; Shiv, et al., 2005). Harga memiliki peran penting dalam penilaian konsumen terhadap suatu barang. Konsumen akan menilai harga dengan membandingkan produk hedonis dengan produk fungsional. Meskipun demikian, ketika harga meningkat maka penilaian terhadap suatu barang cenderung mengalami kesalahan dan pembeli seringkali kurang memahami produk karena kurangnya frekuensi pembelian. Seperti yang dikatakan orang-orang, "kamu mendapatkan apa yang kamu bayar" (Rao \& Monroe, 1989).

\section{Atmospheric Cues}

Atmospheric cues pertokoan dewasa ini telah menjadi alat pemasaran penting dan membedakan dengan toko yang lain yang menjadi pesaingnya. Lingkungan toko menunjukkan lingkungan secara fisik, terdiri dari elemen seperti musik, pencahayaan, layout, simbol, manusia yang ada di sekitarnya (Lin \& Chiang, 2010), lokasi, kualitas, suhu ruangan, tipe-tipe produk, warna, harga, pengiklanan, tenaga penjual, display, dan konstruksi bangunan (Liao et al., 2012). Selain itu, suatu tanda atmosferik toko terdiri dari sejumlah komponen yang terdiri dari pencahayaan, suara, wewangian, dan pegawai toko. Komponen ini dapat digolongkan kedalam faktor ambient, faktor desain, dan faktor sosial yang memiliki kontribusi terhadap kondisi latar belakang toko yang cenderung berdampak terhadap kesadaran konsumen (El Meniawy, 2012). Bentuk kesadaran konsumen adalah mengenai kondisi fisik toko baik internal maupun 
eksternal. Oleh karena itu, ketika konsumen pergi ke toko untuk berbelanja, maka elemen-elemen fisik tersebut menjadi salah satu pertimbangan obyektifitas konsumen tentang keputusan pembelian barang. Tujuan utama pembentukan elemen-elemen lingkungan toko ini adalah menciptakan dan mendorong konsumen agar lebih menikmati suasana di dalam toko (Rahmawan et al., 2013).

\section{Konsumsi Hedonis}

Hirschman \& Holbrook (1982) mendefinisikan konsumsi hedonis sebagai aspekaspek yang terdapat pada perilaku konsumen yang terhubung dengan multisensory, fantasi, dan aspek emotif pengalaman seseorang dengan produk-produk tertentu. Multisensory berarti penerimaan yang bersumber dari luar dan merangsang lima panca indera yang dimiliki oleh manusia. Kelima panca indera tersebut diantaranya adalah pengecap, pendengar, pembau, penglihatan, dan peraba. Dengan kata lain, konsumen akan mendapatkan stimuli (rangsangan) dari lingkungan sekitar. Sebagai contoh, untuk indera pengecap, konsumen diberikan sampel makanan atau minuman oleh pelayan toko sehingga mereka bisa menentukan apakah produk tersebut disukai atau bahkan tidak disukai.

Alba \& Williams (2013) menjelaskan bahwa menentu kesenangan tergolong ke dalam dua kategori yaitu produk atau event (dan kualitas yang melekat) dan pengalaman pribadi konsumen dengan atau terhadap interpretasinya pada produk/event. Mereka menambahkan bahwa kesenangan yang melekat pada hedonisme konsumen didorong oleh fitur produk yang menurut konsumen secara psikologis menyenangkan. Hal tersebut didapatkan konsumen ketika mereka berbelanja di mal atau pusat perbelanjaan.

\section{Ekuitas Merek}

Ekuitas merek didefinisikan sebagai sekumpulan aset merek dan liabilitas, terkait dengan nama merek dan simbol, nilai yang dihasilkan dari suatu produk atau jasa, dan menyediakan nilai kepada pelanggan dan perusahaan (Aaker, 1992). Ekuitas merek merupakan aset tidak berwujud yang dimiliki oleh perusahaan. Selain itu, ekuitas merek juga menjadi sumber penciptaan nilai terhadap suatu produk. Jadi, semakin tinggi nilai suatu produk maka semakin tinggi pula ekuitas merek yang melekat pada produk tersebut. Jika perusahaan menginginkan ekuitas merek sebagai salah satu tujuannya, maka perlu untuk mempelajari dimensi-dimensinya yang terdiri dari brand awareness, brand association, perceived quality, brand trust, dan brand loyalty (Aaker, 1992; Çal \& Adams, 2014). Ekuitas merek merupakan kekuatan dari sebuah merek produk. Perusahaan yang memiliki merek merek produk yang kuat dapat mengelola aset-aset dengan lebih baik dibandingkan dengan pesaingnya, pendapatan lebih banyak, peningkatan kas masuk, market share yang meningkat, mempermudah melakukan pengiklanan, mempermudah melakukan promosi, meningkatkan keunggulan kompetitif, dan lain sebagainya. Istilah ekuitas merek seringkali terbalik-balik dan seringkali disalahartikan sebagai nilai merek, ekuitas merek merujuk kepada kepentingan pelanggan atau konsumen terhadap produk terkait dengan permintaan atau harga premium produk branded sementara nilai merek lebih menunjukkan bagaimana suatu merek bermanfaat bagi perusahaan (Çal \& Adams, 2014).

\section{Perilaku Pembelian Impulsif}

Di dalam perilaku konsumen terdapat pembelian terencana dan pembelian tidak terencana (pembelian impulsif). Ketika akan melakukan perencanaan pembelian, konsumen akan menilai, mengevaluasi, mengatur, dan mengetahui barang apa saja yang harus dibeli sebelum melakukan pembelian sebenarnya di toko. Selain 
itu, konsumen juga sudah mempertimbangkan untuk membeli dan membuat keputusan untuk membeli pada merek tertentu atau tidak membeli sama sekali (Bucklin \& Lattin, 1991), termasuk juga pengecekan dan evaluasi barang yang dibutuhkan dan diinginkan. Konsumen memutuskan melakukan pembelian produk dan akan melakukan pembelian dengan memperhitungkan biaya dan manfaat dari alternatif-alternatif yang ada untuk memaksimalkan benefit yang ingin diperoleh (Meng \& Xu, 2012).

Berbeda dari pembelian terencana, pembelian impulsif terjadi pada saat seorang individu mengalami suatu keinginan mendadak, seringkali kuat, dan gigih untuk membeli sesuatu dengan segera. Pembelian impulsif secara hedonis adalah hal yang kompleks dan dapat memicu konflik emosional (Rook, 1987). Perilaku pembelian ini umumnya berarti pembelian yang tidak direncanakan. Beatty \& Ferrell (1998) kemudian mengembangkan definisi pembelian impulsif tersebut menjadi suatu pembelian mendadak dan segera. Hal penting yang dapat diambil dari definisi kedua peneliti tersebut menunjukkan bahwa perilaku pembelian impulsif adalah tindakan yang dilakukan konsumen tanpa melihat dan mempertimbangkan perencanaan yang dilakukan sebelum terjadinya tindakan pembelian.

\section{HIPOTESIS}

\section{Pengaruh efek plasebo harga terhadap ekuitas merek}

Beberapa toko, mal, atau pusat perbelanjaan memberikan harga tertentu terhadap barang yang dijual. Penetapan harga ini ditujukan untuk mempengaruhi efek psikologis konsumen untuk memilih dan membeli barang yang diinginkan. Salah satu contoh adalah diskon yang dapat mengarahkan konsumen terdapat suatu kondisi efek plasebo (Kim \& Shawn, 2013). Beberapa elemen ekuitas merek (Aaker, 1992) adalah persepsi kualitas yang menjelaskan alasan konsumen untuk membeli, membedakan posisi suatu produk dibandingkan dengan pesaingnya, dan harga. Beberapa pembeli bahkan bersedia membayar produk dengan harga yang lebih mahal karena mereka percaya bahwa harga yang lebih tinggi terkait dengan kualitas yang lebih tinggi (Kim \& Shawn, 2013). Selain itu, elemen ekuitas merek kedua konsumen yang memiliki pengalaman plasebo harga akan lebih sadar merek (brand awareness) karena mereka yakin bahwa sadar terhadap merek produk dan paham perusahaan apa saja yang memiliki merek dengan harga produk yang tinggi, kemudian dengan harga yang tinggi pasti memiliki kualitas yang tinggi pula. Konsumen atau pembeli yang mengalami efek plasebo harga cenderung akan loyal terhadap merek produk dengan harga yang tinggi.

H1: efek plasebo harga berpengaruh positif terhadap ekuitas merek.

\section{Pengaruh efek plasebo harga terhadap konsumsi hedonis}

Seorang konsumen yang memiliki persepsi, ekspektasi, dan harapan konsumen terhadap kinerja suatu produk yang memiliki harga tinggi dalam efek plasebo harga mengalami keterkaitan dengan manfaat hedonis yang ditawarkan oleh produk tersebut (Kim \& Shawn, 2013). Salah satu hal yang penting dalam pertimbangan konsumen dalam memilih merek suatu produk yaitu faktor harga. Untuk jenis produkproduk tertentu dalam pusat perbelanjaan atau mal, harga tidak hanya berupa sejumlah uang yang dikeluarkan oleh konsumen tetapi juga benefit atau manfaat yang diterima oleh konsumen yang dapat berupa kualitas kinerja produk yang unggul.

Pemasar, toko, perusahaan, atau pusat perbelanjaan harus memahami dengan tepat hubungan antara kepercayaan harga konsumen terhadap suatu produk dan keterkaitannya dengan kualitas produk aktual karena masalah tersebut merupakan hal yang penting demi kelangsungan bisnis yang dijalankan. Pebisnis atau pemasar 
bisa mendapatkan keuntungan dengan menekankan pada faktor harga yang dapat memuaskan kebutuhan hedonis konsumennya. Harga yang tinggi dapat memberikan sebuah sinyal kepada konsumen tentang penilaian kualitas konsumsi hedonis, seperti yang ditunjukkan dalam penelitian Kim \& Shawn (2013).

H2: efek plasebo harga berpengaruh positif terhadap konsumsi hedonis

\section{Pengaruh atmospheric cues terhadap konsumsi hedonis}

Menurut Hirschman \& Holbrook (1982) konsumsi hedonis merupakan perilaku konsumen yang terkait dengan faktor multisensory, fantasi, dan emosi seseorang tentang produk. Sehingga konsumen hedonis lebih memilih kesenangan dalam membeli produk. Pebisnis berusaha untuk membuat konsumen hedonis untuk betah berlama-lama di toko supaya mereka dapat memuaskan panca indera konsumen. Konsumen hedonis merasa terhibur ketika berada di dalam atmosfer toko yang telah dibuat sedemikian rupa oleh pihak retailer, manajemen, mal, atau pusat perbelanjaan. Retailer juga berusaha memberikan pengalaman-pengalaman tertentu untuk konsumen tersebut melalui penglihatan, pendengaran, penciuman, dan peraba (Kim, 2001). Penelitian tentang hubungan antara atmospheric cues terhadap konsumsi hedonis telah dilakukan oleh Ballantine et al.(2010).

Beberapa indera pada konsumen dapat distimulasi sesuai dengan fungsinya masing- masing, misalkan seperti indera pendengar dapat dirangsang dengan menggunakan lagu atau musik tertentu. Indera penglihatan dengan menggunakan atau menampilkan media visual yang dengan nuansa pewarnaan tertentu untuk menarik konsumen. Indera pembau (hidung) dirangsang dengan menggunakan wewangian atau parfum tertentu, misalkan seperti di mal yang menggunakan aroma kopi. Pada akhirnya, berdasarkan stimuli terhadap masing-masing sensor/panca indera konsumen atau pengunjung toko akan membentuk suatu persepsi dan pengalaman. Selain itu, melalui stimuli-stimuli tersebut, pemasar akan lebih mudah meningkatkan awareness (kesadaran) terhadap suatu merek.

H3: atmospheric cues berpengaruh positif terhadap konsumsi hedonis

\section{Pengaruh konsumsi hedonis terhadap ekuitas merek}

Seringkali perilaku konsumsi hedonis cenderung membeli produk yang berkualitas dan bermerek. Mereka merasa bangga dengan melakukan pembelian produk merek yang mahal karena yakin bahwa produk tersebut berbeda dengan produk pesaing yang harganya lebih murah. Mereka merasa lebih prestisius ketika mampu membeli produk dengan harga yang lebih mahal. Selain itu, mereka juga cenderung membeli produk bermerek untuk memenuhi hasratnya dan menjadi pusat perhatian (Indrawati, 2015). Apabila dikaitkandengan dimensi ekuitas merek yaitu brand awareness, brand association, perceived quality, brand trust, dan brand loyalty (Aaker, 1992) maka pengunjung mal yang melakukan konsumsi hedonis sudah mencakup atau terlibat dalam beberapa dimensi tersebut. Konsumen hedonis selalu aware terhadap produk merek mahal, memandang kualitas merek perusahaan tertentu secara positif, percaya bahwa merek yang berkualitas berasal dari produk dengan harga yang cenderung lebih mahal, tentunya mereka juga loyal terhadap merek tertentu yang dapat mendukung sifat hedonis yang dimiliki Pemasar dan pebisnis mengambil kesempatan ini untuk membangun ekuitas merek.

H4: konsumsi hedonis berpengaruh positif terhadap ekuitas merek

\section{Pengaruh konsumsi hedonis terhadap perilaku pembelian impulsif}

Konsumsi hedonis dapat mengarah kepada impulsive buying behavior (perilaku pembelian impulsif). Seorang konsumen melakukan pengambilan keputusan atau 
pilihan dengan pembenaran-pembenaran atau justifikasi tertentu dengan mudah (selflicensing) (Huberts et al.,2014). Dengan kata lain, seorang konsumen apabila ingin memutuskan untuk membeli produk di mal, meskipun tidak sesuai dengan kebutuhannya tetapi menggunakan perilaku impulsifnya (konsumsi hedonis) maka ia akan menganggap bahwa keputusannya sudah tepat.

Pembelian impulsif memainkan peran yang penting bagi konsumsi hedonis pengunjung mal dan pusat perbelanjaan di Yogyakarta. Peran pembelian impulsif konsumen merupakan indikator ikatan konseptual antara motivasi pembelian hedonis dengan pembelian impulsif, dengan kata lain konsumen sebagian besar akan melakukan pembelian impulsif apabila mereka merasa ingin memenuhi kebutuhan hedonis akan suatu merek produk perusahaan (Vazifehdoost et al., 2014). Nandha et al., (2017) melakukan penelitian tentang dampak tendensi konsumsi hedonis terhadap perilaku pembelian impulsif dan hasil menunjukkan bahwa terdapat pengaruh signifikan antara tendensi konsumsi hedonis terhadap perilaku pembelian impulsif.

H5: konsumsi hedonis berpengaruh positif terhadap perilaku pembelian impulsif

\section{METODE PENELITIAN}

Penelitian ini dilakukan di beberapa mal atau pusat perbelanjaan yang terletak di Yogyakarta. Teknik sampling yang digunakan adalah non-probability sampling yaitu setiap anggota populasi tidak memiliki kesempatan sama untuk terpilih lagi untuk menjadi sampel. Sementara untuk populasi penelitian adalah semua konsumen yang pernah mengunjungi mal di Yogyakarta. Metode pengumpulan data menggunakan purposive sampling, yakni peneliti menentukan sendiri sampel yang diambil karena beberapa pertimbangan-pertimbangan tertentu, sehingga sampel diambil tidak secara acak.

Kriteria responden adalah pengunjung toko di mal baik pria dan wanita minimal berusia 17 tahun atau yang sudah memasuki usia produktif. Alasan memilih usia produktif adalah karena rasionalitas yang dimiliki segmen responden ini. Konsumen ini sudah dapat membedakan tipe perilaku pembelian apa yang mereka lakukan, pembelian utilitarian yaitu pembelian berdasarkan manfaat (pembelian rasional) pembelian hanya berdasarkan pada konsumsi hedonis (kesenangan). Selain itu responden sudah dapat memahami poin-poin pertanyaan yang tercantum pada kuesioner yang diberikan.

Semua poin pertanyaan yang ada di dalam kuesioner berupa pertanyaan tertutup dengan mengadaptasikan skala likert yang terdiri dari lima skala pertanyaan dari pernyataan sangat tidak setuju sampai sangat setuju (1-5). Nilai 1 berarti sangat tidak setuju dengan pernyataan yang tertera di kuesioner, nilai 2 berarti tidak setuju, nilai 3 berarti kurang setuju, nilai 4 bermakna setuju, dan yang terakhir yaitu nilai 5 menyatakan bahwa responden sangat setuju dengan pernyataan yang ada di kuesioner. Skala lima poin yang dikembangkan oleh Likert (1951) tersebut diadaptasi ke semua variabel-variabel penelitian ini.

\section{Variabel penelitian}

Terdapat 5 variabel yang digunakan dalam penelitian ini yaitu:

1. Price Placebo Effect (Efek Plasebo Harga)

2. Atmospheric Cues

3. Hedonic Consumption (Konsumsi Hedonis),

4. Brand Equity (Ekuitas Merek)

5. Impulsive Buying Behavior (Perilaku Pembelian Impulsif).

Hubungan kelima variabel penelitian dapat dilihat seperti model penelitian berikut: 


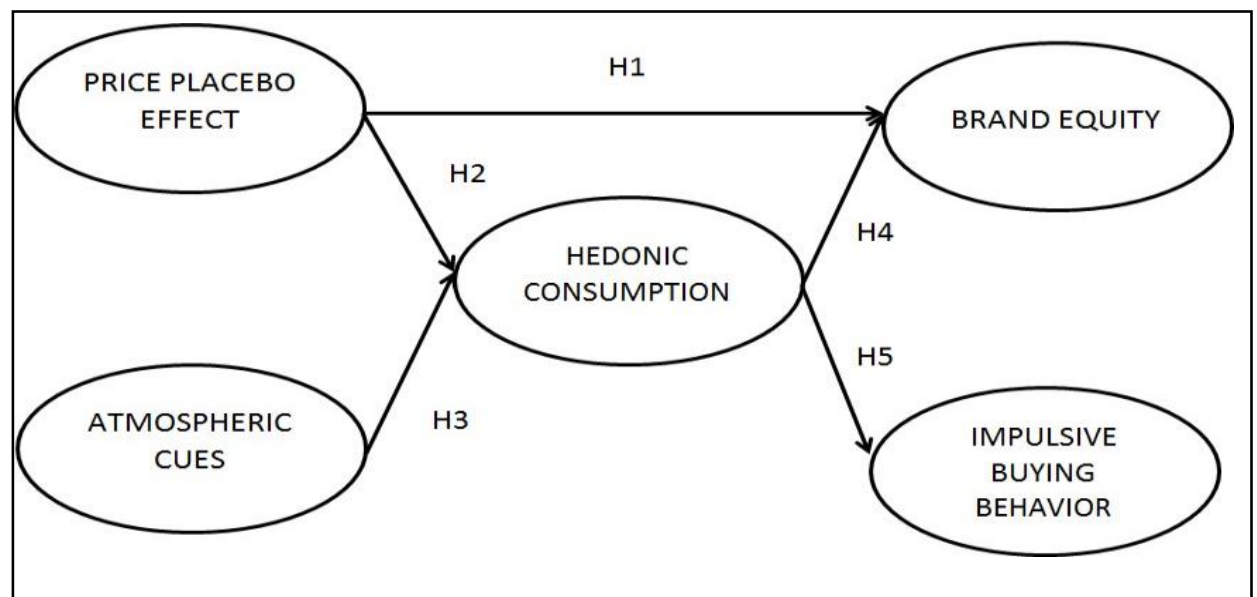

Gambar 1. model penelitian

\section{HASIL DAN PEMBAHASAN}

Sebelum melakukan pengujian data terlebih dahulu peneliti melakukan uji instrumen yaitu uji validitas dan reliabilitas. Pengujian dilakukan untuk menguji apakah kuesioner (instrumen) yang disusun sudah memenuhi asumsi validitas dan reliablitas. Uji validitas bertujuan untuk mengukur tingkat keabsahan dari instrumen (kuesioner) yang digunakan dalam pengumpulan data. Sedangkan uji reliabilitas dilakukan untuk mengetahui keakuratan dan ketepatan dari suatu alat ukur dalam suatu prosedur pengukuran (Widodo, 2006). Uji validitas menggunakan SPSS 16 dengan menggunakan analisis faktor dan dinyatakan valid apabila memenuhi syarat factor loading lebih besar dari 0.5 ( $>0.5)$. Sedangkan alat uji reliabilitas adalah cronbach's alpha. Berikut hasil uji validitas penelitian: 
Ardiyanto dan Umam/ Jurnal Manajemen, Vol 8, No 2 (2018): 97 - 110

Tabel 1. Uji Validitas Instrumen Penelitian

\begin{tabular}{|c|c|c|c|}
\hline Variabel & Item & $\begin{array}{l}\text { Factor } \\
\text { Loading }\end{array}$ & Status \\
\hline \multirow[t]{3}{*}{ Efek Plasebo Harga (PPE) } & 1 & 0.940 & Valid \\
\hline & 2 & 0.896 & Valid \\
\hline & 3 & 0.869 & Valid \\
\hline \multirow[t]{4}{*}{ Atmospheric Cues (ACU) } & 1 & 0.850 & Valid \\
\hline & 2 & 0.895 & Valid \\
\hline & 3 & 0.900 & Valid \\
\hline & 4 & 0.865 & Valid \\
\hline \multirow[t]{4}{*}{ Konsumsi Hedonis (HCO) } & 1 & 0.813 & Valid \\
\hline & 2 & 0.923 & Valid \\
\hline & 3 & 0.901 & Valid \\
\hline & 4 & 0.868 & Valid \\
\hline \multirow[t]{4}{*}{ Ekuitas Merek (BEQ) } & 1 & 0.897 & Valid \\
\hline & 2 & 0.858 & Valid \\
\hline & 3 & 0.849 & Valid \\
\hline & 4 & 0.874 & Valid \\
\hline \multirow[t]{4}{*}{ Perilaku Pembelian Impulsif (IB) } & 1 & 0.969 & Valid \\
\hline & 2 & 0.904 & Valid \\
\hline & 3 & 0.913 & Valid \\
\hline & 4 & 0.912 & Valid \\
\hline
\end{tabular}

Sumber: data olahan

Berdasarkan tabel 1 seluruh item pertanyaan untuk setiap variabel penelitian yang dinyatakan valid, karena nilai factor laoding dari 0.5 (> 0.5). Dengan demikian, semua item pernyataan mampu memerankan tugasnya sebagai alat ukur, atau menghasilkan alat ukur yang sesuai dengan maksud dan tujuan diadakannya pengukuran penelitian.

Berikut ini adalah hasil dari uji reliabilitas untuk masing-masing variabel:

Tabel 2. Uji Reliabilitas Intrumen Penelitian

\begin{tabular}{llcl}
\hline \multicolumn{1}{c}{ Variabel } & Item & $\begin{array}{c}\text { Cronbach's } \\
\text { Alpha }\end{array}$ & Status \\
\hline Efek Plasebo Harga (PPE) & 3 & 0.940 & Reliabel \\
Atmospheric Cues (ACU) & 4 & 0.850 & Reliabel \\
Konsumsi Hedonis (HCO) & 4 & 0.813 & Reliabel \\
Ekuitas Merek (BEQ) & 4 & 0.897 & Reliabel \\
Perilaku Pembelian Impulsif (IB) & 4 & 0.969 & Reliabel \\
\hline
\end{tabular}

Sumber: data olahan

Berdasarkan tabel 2 maka dapat disimpulkan bahwa semua item pernyataan variabel penelitian memenuhi syarat uji reliabilitas, karena nilai cronbach's alpha lebih dari 0.6 maka dikatakan reliabel. 


\section{Uji Model Fit}

Untuk melakukan pengujian model fit melalui Structural Equation Modelling (SEM) peneliti menggunakan program SPSS AMOS 21 dengan metode analisis jalur. Pengujian dilakukan dengan cara melihat hasil output sehingga dapat diketahui apakah model secara umum memiliki model fit yang baik. Selanjutnya, pengujian hipotesis dapat dilakukan sesuai dengan model yang diteliti. Tabel 3 berikut ini menunjukkan model fit penelitian dilakukan.

Tabel 3. Model Fit

\begin{tabular}{llll}
\hline Model Fit Indices & Kriteria & Skor & Evaluasi Model \\
\hline Chi Square & $\begin{array}{l}\text { Diharapkan } \\
\text { kecil } \\
\text { 1-2 over fit, 2- } \\
\text { 5 liberal } \\
\text { limit }\end{array}$ & 524.176 & Kurang Baik \\
CMIN/DF & $>0.9$ & 3.566 & Liberal Limit \\
GFI & $>0.80$ & 0.903 & Baik \\
AGFI & $>0.9$ & 0.874 & Baik \\
TLI & $>0.9$ & 0.897 & Cukup Baik \\
CFI & $<0.08$ upper limit & 0.911 & Baik \\
RMSEA & $<0.1$ & 0.071 & Baik \\
\hline
\end{tabular}

Sumber: data olahan

Nilai GFI (Goodness of Fit) sebesar 0.903. Semakin nilai GFI mendekati angka 1 maka semakin baik, jadi nilai kesesuaian antara model dengan data dalam penelitian ini dapat dikatakan baik. Nilai CFI (Comparative Fit Index) sebesar 0.911. Semakin nilai CFI mendekati angka 1 maka semakin baik, jadi nilai kesesuaian antara model dengan data dalam penelitian ini dapat dikatakan baik.

Nilai TLI (Tucker Lewis Index) sebesar 0.897 dapat dikatakan cukup baik karena nilainya mendekati angka 1. Nilai AGFI (Adjusted Goodness of Fit) sebesar 0.874 juga dapat dikatakain baik karena melebihi batas kriteria 0.8. Nilai CMIN/DF berada di batas liberal limit (2-5) yaitu 3.566. Nilai RMSEA (Root Mean Square Error of Approximation) sebesar

0.071 termasuk dalam kriteria baik, karena memenuhi kriteria penerimaan model dengan tidak melebihi batas atas 0,8. Secara keseluruhan dapat disimpulkan bahwa beberapa index model fit pada tabel di atas baik (fit).

\section{Uji Hipotesis}

Hipotesis H1 sampai dengan H5 diuji dengan menggunakan path analysis (analisis jalur) program SPSS AMOS 21. Uji hipotesis ini digunakan untuk mengetahui 
pengaruh variabel dependen terhadap variabel independen penelitian. Berikut ini tabel hasil pengujian hipotesis penelitian.

Tabel 4. Hasil Pengujian Hipotesis

\begin{tabular}{|c|c|c|c|c|}
\hline Hipotesis & Pernyataan Hipotesis & $\begin{array}{l}\text { Standardized } \\
\text { Regression } \\
\text { Weights (B) }\end{array}$ & P-Value & Keterangan \\
\hline H1 & $\begin{array}{l}\text { Efek plasebo harga berpengaruh } \\
\text { positif terhadap ekuitas merek }\end{array}$ & $\begin{array}{l}0.23 \\
4\end{array}$ & $<0.001$ & Didukung \\
\hline $\mathrm{H} 2$ & $\begin{array}{l}\text { Efek plasebo harga berpengaruh } \\
\text { positif terhadap konsumsi } \\
\text { hedonis }\end{array}$ & $\begin{array}{l}0.24 \\
1\end{array}$ & $<0.001$ & Didukung \\
\hline H3 & $\begin{array}{l}\text { Atmospheric cues berpengaruh } \\
\text { positif terhadap konsumsi } \\
\text { hedonis }\end{array}$ & $\begin{array}{l}0.29 \\
7\end{array}$ & $<0.001$ & Didukung \\
\hline $\mathrm{H} 4$ & $\begin{array}{l}\text { Konsumsi hedonis berpengaruh } \\
\text { positif terhadap ekuitas merek }\end{array}$ & $\begin{array}{l}0.50 \\
0 \\
\end{array}$ & $<0.001$ & Didukung \\
\hline H5 & $\begin{array}{l}\text { Konsumsi hedonis berpengaruh } \\
\text { positif terhadap perilaku } \\
\text { pembelian impulsif }\end{array}$ & $\begin{array}{l}0.35 \\
5\end{array}$ & $<0.001$ & Didukung \\
\hline
\end{tabular}

Sumber: data olahan

Berdasarkan hasil pengujian hipotesis maka dapat diketahui beberapa hal sebagai berikut:

Hipotesis $\mathrm{H} 1$ yang menyatakan bahwa efek plasebo harga (PPE) berpengaruh positif terhadap ekuitas merek (BEQ) terbukti didukung $(B=0.234$ pada $p$-value $<0.001)$. Hal ini menunjukkan semakin tinggi efek plasebo harga terhadap konsumen dan pengujung mal serta pusat perbelanjaan di Yogyakarta maka semakin besar pula ekuitas merek suatu produk yang dipandan oleh konsumen tersebut. Konsumen yang mengalami kondisi efek plasebo harga akan sadar (aware) terhadap merek perusahaan yang mereka sukai, karena konsumen tersebut cenderung loyal terhadap merek.

Hipotesis $\mathrm{H} 2$ yang menyatakan bahwa efek plasebo harga (PPE) berpengaruh positif terhadap konsumsi hedonis $(\mathrm{HCO})$ terbukti didukung $(B=0.241$ pada $\mathrm{p}$-value $<0.001$ ). Hal ini dapat membuktikan bahwa semakin tinggi efek plasebo harga seorang konsumen maka ia cenderung melakukan konsumsi hedonis. Hasil pengujian hipotesis H2 ini juga mengkonfirmasi penelitian Kim \& Shawn (2013) yang membuktikan bahwa efek plasebo harga terdapat pada settings konsumsi hedonis.

Hipotesis H3 yang menyatakan bahwa atmospheric cues (ACU) berpengaruh positif terhadap konsumsi hedonis $(\mathrm{HCO})$ terbukti didukung $\left(B=0.297\right.$ pada $\mathrm{p}^{-}$value $<0.001$ ). Hal ini menunjukkan bahwa apabila toko, mal, dan pusat perbelanjaan memberikan stimuli terhadap panca indera konsumen seperti penglihatan, pendengaran, dan peraba maka konsumen tertarik untuk melakukan konsumsi hedonis dengan cara membeli produk dengan merek tertentu di toko tersebut. Pebisnis berusaha untuk membuat konsumen hedonis untuk betah berlama-lama di toko supaya mereka dapat memuaskan panca indera konsumen. Selain itu, hasil uji hipotesis ini mengkonfirmasi penelitian Ballantine et al.(2010) yang meneliti tentang efek atmospheric cues terhadap pengalaman hedonis retail.

Hipotesis $\mathrm{H} 4$ yang menyatakan bahwa konsumsi hedonis (HCO) berpengaruh 
positif terhadap ekuitas merek (BEQ) terbukti didukung $\left(B=0.500\right.$ pada $p^{\text {-value }}$ $<0.001$ ). Hal ini menunjukkan bahwa perilaku konsumsi hedonis konsumen dapat meningkatkan ekuitas merek perusahaan. Pengujian hipotesis ini mengkonfirmasi penelitian Çal \& Adams(2014) tentang dampak hubungan antara perilaku konsumen hedonistik dan utilitarian terhadap ekuitas merek dengan membandingkan konsumen yang berasal dari negara Turki dengan Inggris.

Hipotesis $\mathrm{H} 5$ yang menyatakan bahwa konsumsi hedonis (HCO) berpengaruh positif terhadap perilaku pembelian impulsif (IB) terbukti didukung $\left(B=0.355\right.$ pada $\mathrm{p}^{-}$ value $<0.001$ ). Hipotesis ini mengkonfirmasi penelitian Nandha et al., (2017) tentang dampak tendensi konsumsi hedonis terhadap perilaku pembelian impulsif dan hasil menunjukkan bahwa terdapat pengaruh signifikan antara tendensi konsumsi hedonis terhadap perilaku pembelian impulsif.

\section{PENUTUP}

Penelitian telah membuktikan beberapa kondisi perilaku berbelanja konsumen Mal di Yogyakarta yang berlokasi di Galeria Mall, Jogjatronik Mall, Malioboro Mall, Lippo Plaza Jogja, Ramai Family Mall, Ambarrukmo Plaza, Mirota Kampus, Gardena, Jogja City Mall, Hartono Mall, Sahid J-Walk Mall, dan Toko Progo. Oleh karena itu dapat disimpulkan beberapa hal sebagai berikut.

Pertama, Efek plasebo harga berpengaruh positif terhadap ekuitas merek terbukti didukung menunjukkan bahwa semakin tinggi efek plasebo harga terhadap konsumen dan pengujung mal serta pusat perbelanjaan di Yogyakarta maka semakin besar pula ekuitas merek suatu produk yang dipandang oleh konsumen tersebut. Konsumen yang mengalami kondisi efek plasebo harga akan sadar (aware) terhadap merek perusahaan yang mereka sukai, karena konsumen tersebut cenderung loyal terhadap merek, dan selalu menjadikan merek tertentu sebagai pilihan utama ketika berbelanja sehingga hal tersebut akan menguntungkan perusahaan.

Kedua, Efek plasebo harga berpengaruh positif terhadap konsumsi hedonis terbukti didukung. Sehingga hal ini dapat membuktikan bahwa semakin tinggi efek plasebo harga seorang konsumen maka ia cenderung melakukan konsumsi hedonis. Ketiga, Atmospheric cues berpengaruh positif terhadap konsumsi hedonis terbukti didukung. Hal ini menunjukkan bahwa apabila toko, mal, dan pusat perbelanjaan memberikan stimuli terhadap panca indera konsumen seperti penglihatan, pendengaran, dan peraba maka konsumen tertarik untuk melakukan konsumsi hedonis dengan cara membeli produk dengan merek tertentu di toko tersebut. Pebisnis berusaha untuk membuat konsumen hedonis untuk betah berlama-lama di toko supaya mereka dapat memuaskan panca indera konsumen.

Ketiga, konsumsi hedonis berpengaruh positif terhadap ekuitas merek terbukti didukung. Hal ini menunjukkan bahwa perilaku konsumsi hedonis konsumen dapat meningkatkan ekuitas merek perusahaan. Konsumen hedonis menganggap bahwa membeli barang merupakan hal yang menyenangkan. Kelima, Konsumsi hedonis berpengaruh positif dan signifikan terhadap perilaku pembelian impulsif terbukti didukung. Konsumen yang memiliki sifat ini akan berusaha memenuhi kebutuhan hedonis salah satu caranya dengan melakukan pembelian tidak terencana. Mereka tentunya tertarik dengan produk perusahaan tertentu yang memiliki prestige yang tinggi seolah-olah mampu meningkatkan status sosial mereka di mata orang lain.

\section{REFERENSI}

Aaker, D. A. (1992). The Value of Brand Equity. The Value of Brand Equity, 13(4), 27- 
32.

Alba, J. W., \& Williams, E. F. (2013). Pleasure principles: A review of research on hedonic consumption. Journal of Consumer Psychology, 23(1), 2-18. https://doi.org/10.1016/j.jcps.2012.07.003

Ballantine, P. W., Jack, R., \& Parsons, A. G. (2010). Atmospheric cues and their effect on the hedonic retail experience. International Journal of Retail \& Distribution Management, 38(8), 641-653. https://doi.org/10.1108/09590551011057453

Beatty, S. E., \& Ferrell, M. E. (1998). Impulse Buying : Modeling Its Precursors. Journal of Retailing, 74(2), 169-191.

Bucklin, R. E., \& Lattin, J. M. (1991). A Two-State Model of Purchase Incidence and Brand Choice. Marketing Science, 10(1), 24-39. https://doi.org/10.1287/mksc.10.1.24

Çal, B., \& Adams, R. (2014). The Effect of Hedonistic and Utilitarian Consumer Behavior on Brand Equity: Turkey - UK Comparison on Coca Cola, 150, 475-484. https://doi.org/10.1016/j.sbspro.2014.09.057

El Meniawy, A. M. (2012). Personal Characteristics and Situational Influences Affecting Consumers Adoption of Impulse Buying Behavior. In 3rd International Conference on Business and Economic Research (3rd ICBER 2012) PROCEEDING (pp. 32713282).

Hirschman, E. C., \& Holbrook, M. B. (1982). Hedonic Consumption : Emerging Concepts , Methods and. Journal of Marketing, 46(3), 92-101.

Huberts, J. D. W., Evers, C., \& Ridder, D. De. (2014). Thinking before sinning: reasoning processes in hedonic consumption. Frontiers in Psychology, 5(November), 1-7. https://doi.org/10.3389/fpsyg.2014.01268

Indrawati, D. (2015). Pengaruh Citra Merek Dan Gaya Hidup Hedonis Terhadap Keputusan Pembelian Jilbab "ZOYA ." Jurnal Riset Ekonomi Dan Manajemen, 15(2), 302-319.

Kesari, B., \& Atulkar, S. (2016). Journal of Retailing and Consumer Services Satisfaction of mall shoppers: A study on perceived utilitarian and hedonic shopping values. Journal of Retailing and Consumer Services, 31, 22-31. https://doi.org/10.1016/j.jretconser.2016.03.005

Kienle, G. S., \& Kiene, H. (1997). the Powerful Placebo Effect- Fact or Fiction? J Clin Epidemiol, 50(12), 1311-1318.

Kim, D., \& Shawn, S. (2013). Price Placebo Effect in Hedonic Consumption. International Journal of Hospitality Management, 35, 306-315. https://doi.org/10.1016/j.ijhm.2013.07.004

Kim, S. A., \& Kim, J. (2014). The influence of hedonic versus utilitarian consumption situations on the compromise effect. https://doi.org/10.1007/s11002-014-9331-0

Kim, Y. K. (2001). Experiential retailing:an interdisciplinary approach to success in domestic and international retailing. Journal of Retailing and Consumer Services, \&(5), 287-289. https://doi.org/10.1016/S0969-6989(00)00034-5

Liao, C.-S., Huang, C.-W., Huang, T.-Y., \& Deeseentham, K. (2012). A Cross-Cultural Examination of Store Environment Cues and Purchase Intention in Taiwan and the United States. Journal of Applied Business and Economics, 13(1), 73-83.

Likert, R. (1951). Motivational Dimensions of Administration, 1-59.

Lim, E. A. C., \& Ang, S. H. (2008). Hedonic vs . Utilitarian Consumption : A Crosscultural Perspective Based on Cultural Conditioning. Journal of Business Research, 61, 225-232. https://doi.org/10.1016/j.jbusres.2007.06.004

Lin, M. Q., \& Chiang, Y. F. (2010). The influence of store environment on perceived experiential value and behavior intention. Asia Pacific Management Review, 15(2), 
$281-299$.

Ling, I., Shieh, C., \& Liao, J. (2012). The Higher the Price the Better the Result? The Placebo-Like Effects of Price and Brand on Consumer Judgments. Theoretical Economics Letters, 2, 264-269. Retrieved from http://dx.doi.org/10.4236/tel.2012.23048 Published

Meng, F., \& Xu, Y. (2012). Tourism shopping behavior: planned, impulsive, or experiential?

International Journal of Culture, Tourism and Hospitality Research, 6(3), 250-265. https://doi.org/10.1108/17506181211246401

Nandha, O., Andriani, K., \& Edriana, P. (2017). The Effect of Store Environment, Avalaibility of Money and Time, Hedonic Consumption Tendency on Emotional States and Its Impact On Impulse Buying Behavior. RJOAS, 3(March), 72-78. https://doi.org/10.18551/rjoas.2017-03.09

Rahmawan, I. W., Kumadji, S., \& Kusumawati, A. (2013). Pengaruh Faktor-faktor Lingkungan Toko Terhadap Pembelian Impulsif. Jurnal Administrasi Bisnis, 6(2), $1-10$.

Rao, A. R., \& Monroe, K. B. (1989). The Effect of Price, Brand Name, and Store Name on Buyers' Perceptions of Product Quality: An Integrative Review. Journal of Marketing Research, 26(3), 351-357.

Rook, D. W. (1987). The Buying Impulse. The Journal of Consumer Research, 14(2), $189-199$.

Ryu, K., Han, H., \& Jang, S. (Shawn). (2010). Relationships among hedonic and utilitarian values, satisfaction and behavioral intentions in the fast-casual restaurant Relationships among hedonic and utilitarian values, satisfaction and behavioral intentions in the fast-casual restaurant industr. International Journal of Contemporary Hospitality Management, 22(3), 416-432. https://doi.org/10.1108/09596111011035981

Situmeang, M. K. (2017, September 19). Perilaku Konsumtif dan Tren Shopaholic pada Mahasiswa Indonesia. Retrieved Juni 26, 2018, from Braindilog Sosiologi Indonesia: http://www.braindilogsociology.or.id/2017/09/perilaku-konsumtif-dantren- shopaholic.html

Shiv, B., Carmon, Z., \& Ariely, D. (2005). Placebo Effects of Marketing Actions: Consumers May Get What They Pay For. Journal of Marketing Research, 42(4), 383-393. https://doi.org/10.1509/jmkr.2005.42.4.383

Stewart-Williams, S., \& Podd, J. (2004). The Placebo Effect: Dissolving the Expectancy Versus Conditioning Debate. Psychological Bulletin, 130(2), 324-340. https://doi.org/10.1037/0033-2909.130.2.324

Vazifehdoost, H., Rahnama, A., \& Mousavian, S. J. (2014). Evaluation of the Influence of Fashion Involvement, Personality Characteristics, Tendency to Hedonic Consumption and Store Environment on Fashion-Oriented Impulse Buying. Mediterranean Journal of Social Sciences, 5(16), 223-231. https://doi.org/10.5901/mjss.2014.v5n16p223

Widodo, P. B. (2006). Reliabilitas dan Validitas Konstruk Skala Konsep Diri untuk Mahasiswa Indonesia. Jurnal Psikologi Universitas Diponegoro , 3 (1). 